\title{
A 30-Yr Climatology of Meteorological Conditions Associated with Lightning Days in the Interior Western United States ${ }^{\mathscr{C}}$
}

\author{
Dmitri A. Kalashnikov, Paul C. Loikith, and Arielle J. Catalano \\ Department of Geography, Portland State University, Portland, Oregon \\ DuAne E. WALISER AND HuIKYo LeE \\ Jet Propulsion Laboratory, California Institute of Technology, Pasadena, California
}

JOHN T. ABATZOGLOU

Department of Geography, University of Idaho, Moscow, Idaho, and Management of Complex Systems Department, University of California, Merced, Merced, California

(Manuscript received 24 July 2019, in final form 30 December 2019)

\begin{abstract}
A 30-yr climatology of lightning days and associated synoptic meteorological patterns are characterized across the interior western United States (WUS). Locally centered composite analyses show preferred synoptic meteorological patterns with positive 500-hPa geopotential height anomalies located to the northeast and negative sea level pressure anomalies to the northwest and collocated with local lightning days. Variations in preferred patterns for local lightning days are seen across the interior WUS. Areas not commonly affected by the North American monsoon system including the western Great Basin and northern Rocky Mountains show higher-amplitude anomalies of geopotential height, moisture, and midtropospheric instability patterns suggesting the importance of episodic midlatitude dynamics to lightning days in such locations. By contrast, locations closer to the core of the North American monsoon show weaker anomalies, likely reflecting the prevalence of favorable mesoscale dynamics key to lightning production during warm-season months in locations in the interior Southwest. Meteorological patterns for select locations are explored in more detail and two case studies of notably active lightning events are presented. Results from this observational analysis provide a foundation for evaluating meteorological conditions on lightning days in climate model simulations for the interior WUS.
\end{abstract}

\section{Introduction}

Thunderstorms during warm-season months across interior portions of the western United States (WUS) pose potential hazards ranging from wildfire ignition to flash flooding. Lightning serves as a direct indicator for thunderstorm activity. Cloud-to-ground (CG) lightning (hereafter CG flashes) is a major ignition source for summer wildfires across interior portions of the WUS (Abatzoglou et al. 2016; Dettinger et al. 1999; Nauslar et al. 2019; Rorig and Ferguson 1999; van Wagtendonk

\footnotetext{
T) Supplemental information related to this paper is available at the Journals Online website: https://doi.org/10.1175/JCLI-D-190564.s1.

Corresponding author: Dmitri A. Kalashnikov, dmitri4@pdx.edu
}

and Cayan 2008). Improved understanding of lightning activity can be used to help inform outlooks of lightningrelated hazards on weather-to-centennial time scales. While previous studies have projected an increase in lightning occurrence under anthropogenic climate change globally (Price 2009) and in the conterminous United States (Romps et al. 2014), such conclusions remain uncertain on the regional scale (e.g., Hoogewind et al. 2017; Villarini and Smith 2013). To better inform projections of possible future changes to lightning climatology, more work is needed to quantify the meteorological patterns associated with lightning days in the current climate.

While lightning frequency itself has been found to be of secondary importance to spatiotemporal variability of wildfire when compared with climatic and fuel load conditions in many regions (Abatzoglou et al. 2016; Krawchuk et al. 2009), lightning is the dominant source 
of fire ignitions and burned area in sparsely populated regions of WUS (Balch et al. 2017) in addition to serving as an indicator for other thunderstorm-related impacts such as flash flooding. However, as lightning flashes and therefore thunderstorms are not explicitly simulated by climate models (Magi 2015), understanding how climate change may affect this important feature of the regional summertime climate remains challenging. One way to address this challenge is to evaluate the ability of climate models to simulate synoptic conditions favorable to lightning (Magi 2015; Price and Rind 1992). An understanding of the synoptic-scale weather patterns and meteorological variable indices associated with lightning days in interior portions of WUS is therefore necessary. As continuous lightning detection in WUS only extends to 1985 (Dettinger et al. 1999), studies focused on this region have utilized shorter lightning datasets, typically between 5 and 20 years in length. Shorter datasets may not fully characterize lightning climatology particularly in areas of infrequent thunderstorms, and no publication to the authors' knowledge has characterized lightning activity and associated synoptic patterns on a $30-y r$ baseline in this region.

The overarching goal of the current study is to gain a better understanding of the synoptic patterns associated with lightning days and how they vary spatially across the interior WUS. Previous efforts to describe lightning occurrence in the WUS (Abatzoglou and Brown 2009; Adams and Souza 2009; Burrows et al. 2005; Dettinger et al. 1999; Milne 2004; Rorig and Ferguson 1999; Rorig et al. 2007; van Wagtendonk and Cayan 2008) and southwestern Canada (Burrows et al. 2005; Nash and Johnson 1996) have used a suite of dynamic and thermodynamic variables at synoptic-scale to mesoscale resolution, typically focusing on circulation anomalies as well as indices of moisture and instability. In this study, we retain a combination of variables chosen empirically with selection guided by previous works. We use a comprehensive and spatially contiguous analysis to describe the synoptic-scale meteorological patterns and a subset of thermodynamic variables associated with summertime lightning activity in the interior WUS, and spatial variation thereof in areas within and outside the core monsoon region.

\section{Data and methodology}

\section{a. Data}

We use CG flash data from the National Lightning Detection Network (NLDN). The NLDN is a groundbased lightning sensor network spanning the lower 48 states (Cummins and Murphy 2009; Orville 2008), and has served as ground truth in evaluation of other groundbased lightning detection efforts (e.g., Abarca et al. 2010). Although the NLDN is a private network owned and operated by a commercial vendor, daily gridded lightning data are made available to the National Oceanic and Atmospheric Administration's Severe Weather Data Inventory (NOAA-SWDI). This dataset provides daily temporal resolution on a $0.1^{\circ}$ latitude-longitude grid. We use 30 years of observations spanning the years 19882017, in order to capture the World Meteorological Organization (WMO) specified climatological baseline length in our analysis. Daily meteorological data are obtained from the National Aeronautics and Space Administration's (NASA) Modern-Era Retrospective Analysis for Research and Applications, version 2 (MERRA-2; Gelaro et al. 2017), at a spatial resolution of $0.5^{\circ}$ latitude $\times 0.625^{\circ}$ longitude.

\section{b. Methodology}

Analysis is conducted over the months from May through September (MJJAS), which represents the summertime convective season across WUS (Burrows et al. 2005; Dettinger et al. 1999; Rorig and Ferguson 1999; also see Fig. S1 in the online supplemental material for peak months of lightning activity). At each $0.1^{\circ} \times$ $0.1^{\circ}$ grid cell across the WUS, defined here as the region bounded by latitude $31.5^{\circ}-49^{\circ} \mathrm{N}$ and between the Pacific Ocean to the west and longitude $105^{\circ} \mathrm{W}$ to the east, a lightning day is said to occur when at least five CG flashes are detected. The CG flash threshold is selected to eliminate days in the lower percentiles of lightning activity, while preserving meaningful sample sizes across the study domain. The selection of a relatively low CG flash threshold also minimizes the effects of increasing detection efficiency of the NLDN over time, which has undergone system upgrades during the study period (Cummins and Murphy 2009).

The foundation of our results is a composite analysis of dynamic and thermodynamic anomalies present on lightning days over the 30-yr record. To represent synoptic circulation patterns in the midtroposphere and near the surface, respectively, 500-hPa geopotential height (Z500) and sea level pressure (SLP) are used. Total precipitable water vapor (TQV) provides a vertically integrated snapshot of atmospheric moisture. Instability is represented by the midtropospheric lapse rate, defined as the temperature difference between the 700- and 500-hPa pressure levels (L700500).

The current study makes use of deseasonalized anomalies of these variables, which are computed by subtracting the 30-yr daily climatology (1988-2017) from daily values. To account for substantial variability in TQV climatology across the domain, standardized anomalies are 
TABLE 1. A summary of variables analyzed on lightning days. Variables represent anomalies relative to daily means, with the exception of W700. Italics denote that standard deviation $z$ scores are used.

\begin{tabular}{llc}
\hline \hline \multicolumn{1}{c}{ Variable } & Abbreviation & Units \\
\hline 500-hPa geopotential height & Z500 & $\mathrm{m}$ \\
Sea level pressure & SLP & $\mathrm{hPa}$ \\
700-hPa wind direction & W700 & $\circ$ \\
700-500-hPa lapse rate & L700500 & ${ }^{\circ} \mathrm{C}$ \\
Total precipitable water vapor & TQV & $\mathrm{kg} \mathrm{m}^{-2}$ \\
\hline
\end{tabular}

used. In addition, 700-hPa wind direction (W700) is included in the analysis to understand lower-tropospheric circulation patterns on lightning days. Other variables were considered for analysis including derived parameters utilized in operational forecasting of thunderstorms, such as convective available potential energy (CAPE) and the total totals index. With climate model evaluation providing a sensible extension of this work, we retain large-scale variables amenable to regional climatological analysis over varied topography. A summary of analyzed variables is provided in Table 1. For composite analysis, the spatial domain is further constrained to only those grid cells which average at least one lightning day per year as defined above, ensuring a minimum sample size of 30 lightning days at all analyzed grid cells across the period of record. This results in a total of 24053 grid cells with lightning days included in this study. The 30-day minimum sample size demonstrates the value of using this relatively long lightning climatology record.

Two types of composites of dynamic and thermodynamic meteorological patterns are computed. First, composites of meteorological variables are computed for all lightning days at each of the 24053 grid cells, resulting in 24053 composites (referred to as "local composites" herein). Second, for each variable, all local composites are averaged into a single composite referred to as the "grand composite" herein. Pattern correlation (PC; computed as the Pearson's $r$ ) and rootmean-square deviation (RMSD) are used to compare local composites to the grand composite, and $\mathrm{PC}$ is also used to analyze features of the local composites.

To allow for systematic comparison of meteorological variables from different locations, composite patterns are remapped to polar coordinate grids centered on each grid cell, following the methodology employed for temperature extremes by Loikith and Broccoli (2012). Horizontal resolution of $50 \mathrm{~km}$ and azimuthal resolution of $1^{\circ}$ is selected in order to best approximate the underlying MERRA-2 field. This process standardizes coordinates around each grid cell to a unit circle with absolute distances. An example of one such "gridcellrelative grid" is shown in Fig. 1. The outer boundary of
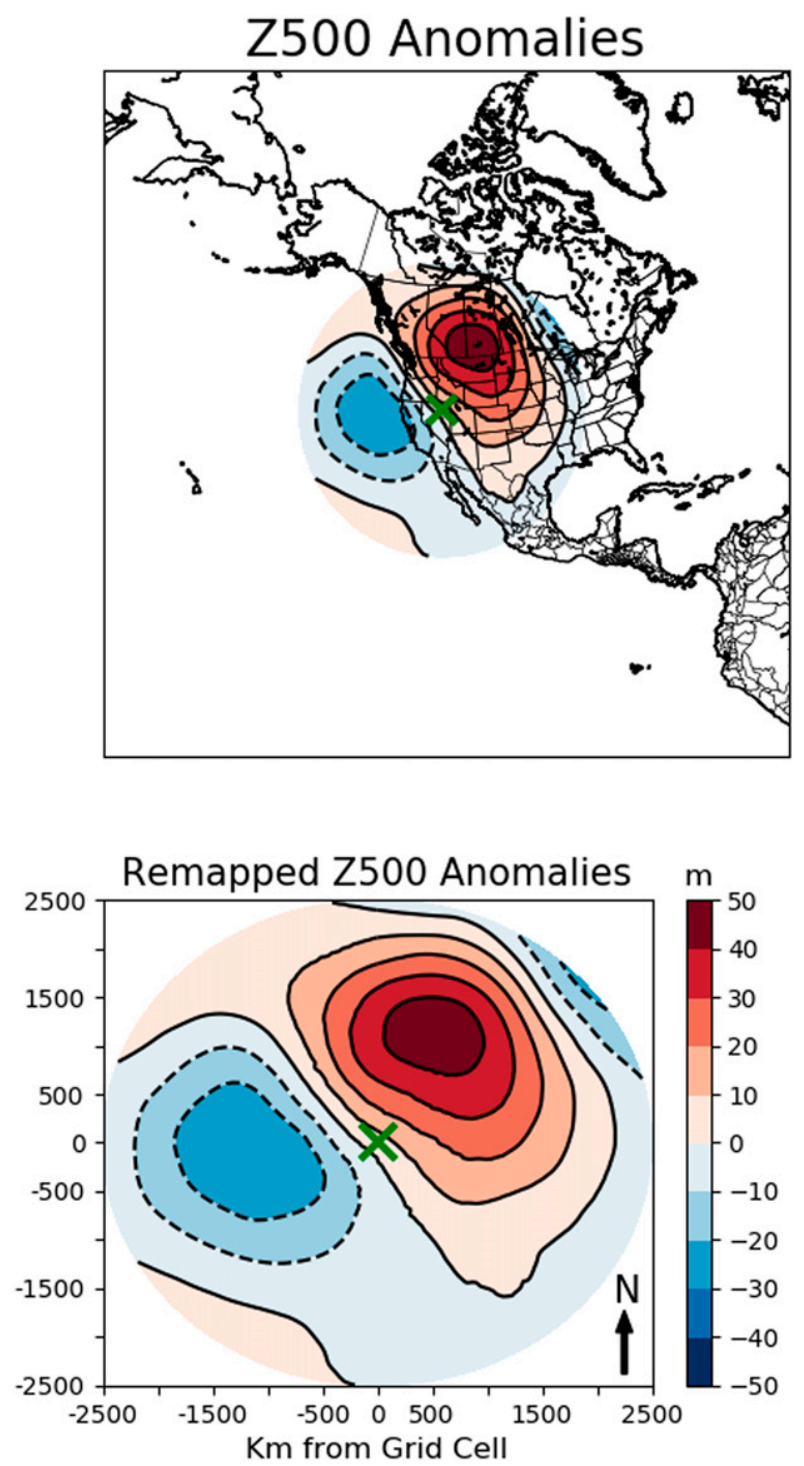

FIG. 1. An illustration of how the gridcell-relative composites are created. (top) Map of Z500 anomalies associated with lightning days at the grid cell represented by the green marker. Only data within $2500 \mathrm{~km}$ of this grid cell are shaded. (bottom) The above data remapped onto the "gridcell-relative grid" using polar coordinates on a unit circle, with the origin set at this grid cell.

the grid is located $2500 \mathrm{~km}$ from the central grid cell, a distance chosen empirically such that large-scale circulation patterns would be captured.

\section{Composite analysis}

A map of the total number of lightning days (19882017), for all grid cells averaging at least one lightning day per year as defined for this study ( $\geq 5$ CG flashes), is presented in Fig. 2 and serves as the set of grid cells $(N=$ 24053 grid cells) retained for composite analysis. It is 


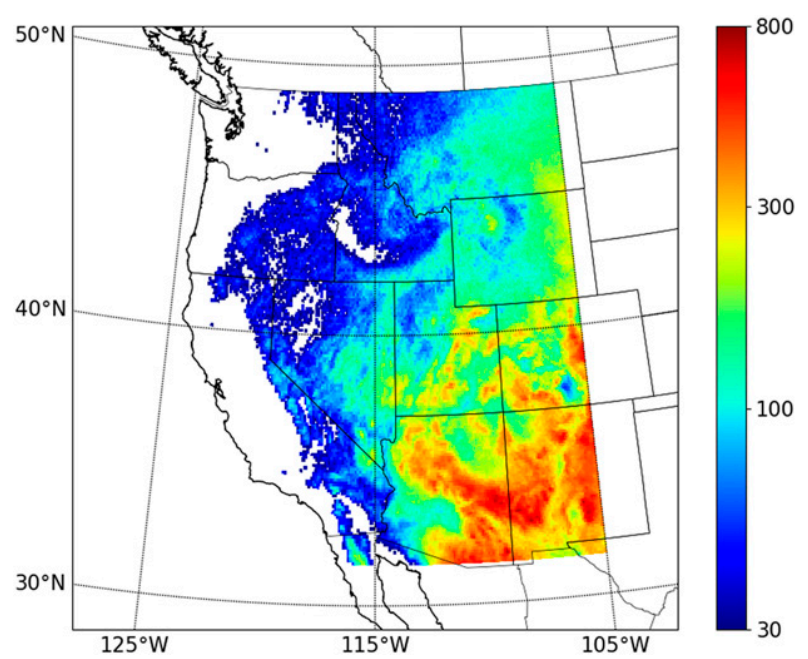

FIG. 2. Total number of days with $\geq 5$ CG flashes (MJJAS, 19882017), per $0.1^{\circ} \times 0.1^{\circ}$ grid cell. Only grid cells with at least 30 such days in the western United States are included in composite analysis. Note that values are plotted on a logarithmic scale.

inherent in our method and from analysis of Fig. 2 that sample sizes at individual grid cells vary based on the climatological prevalence of lightning days. While the minimum sample size is defined as 30 days, maximum sample size ranges as high as 721 days in southwestern New Mexico. The spatial variation of lightning day sample sizes in Fig. 2 resembles that of annual CG flash averages across the domain, with masked areas in this figure generally corresponding to areas with less than 0.1 CG flash $\mathrm{km}^{-2} \mathrm{yr}^{-1}$ (see Fig. S2).

\section{a. Z500 and SLP}

Grand composites of Z500 and SLP anomalies are depicted in Figs. 3a and 3b. Boxplots in Figs. $3 c$ and $3 d$ are provided to show the distribution of individual gridcell anomalies at the locations of anomaly peaks in the grand composites. A Student's $t$ test is performed in order to test the statistical significance of the difference in grand composite anomaly peaks relative to each other, utilizing the sample size of individual gridcell anomalies at those locations relative to each grid cell. Results indicate a statistically significant difference between the positive and negative anomaly peaks in the grand composites of both variables.

Average lightning days across the domain are characterized by positive Z500 anomalies located to the northeast of the grid cell experiencing lightning, with negative Z500 anomalies located to the southwest (Fig. 3a). A gradient in the large-scale circulation pattern is thus apparent, placing the grid cell between positive Z500 anomalies to the north and negative Z500 anomalies to the south. Negative SLP anomalies are located just north of the grid cell experiencing a lightning day (Fig. 3b), which may be associated with a surface thermal trough, as composite analysis of 2-m temperature anomalies shows positive departures displaced northward relative to the average grid cell (not shown). The grand composites are consistent with the canonical large-scale weather pattern conducive to lightning outbreaks in the interior WUS, as previous studies have linked this synoptic setup with increased lightning potential as well as lightning-ignited wildfire risk in this region (Abatzoglou and Brown 2009; Chiodi et al. 2016; Dettinger et al. 1999; Rorig and Ferguson 1999; Werth and Ochoa 1993). Likewise, the location of positive Z500 anomalies is in agreement with studies focusing on the core monsoonal region (Higgins et al. 2004; Lorenz and Hartmann 2006), which found a high pressure ridge to the north and northeast of areas experiencing surges of convective activity. North-northeastward displacement of upper-level ridging thus presents a pattern commonality across the latitudinal extent of the interior WUS on lightning days.

Figure 4 shows PC and RMSD values between the local composite and the grand composite for each grid cell for Z500 and SLP. Median pattern correlation values, computed between the grand composite and all of the individual local composites, are provided as an aggregate metric of the ability of the grand composite to capture common spatial features of the individual composites.

An analysis of Z500 PC coefficients in Fig. 4a reveals generally high levels of similarity between local composite patterns and the grand composite (in Fig. 3a) in the western Great Basin and northern Rocky Mountains, with varying levels of similarity in the interior Southwest. However, the preferred north-northeastward displacement of positive Z500 anomalies (exhibited in the grand composite) relative to each grid cell is evident across the study domain (median pattern correlation: 0.78 ). Our results indicate that in the typical interior WUS location, northeastward displacement of mid- and upper-level ridging can lead to lightning activity regardless of latitude. At the surface, SLP PC coefficients in Fig. 4c show generally high levels of similarity between local composite patterns and the grand composite (in Fig. 3b) in areas farther north, with lower similarity across the interior Southwest. A latitudinal differentiation in preferred surface pressure patterns is apparent from this figure, as most locations approximately south of $38^{\circ} \mathrm{N}$ latitude lack the characteristic surface pressure anomaly pattern found in the grand composite.

Corresponding maps of Z500 (Fig. 4b) and SLP (Fig. 4d) RMSD statistics show that the highest similarities between local and grand composites (in Figs. 3a,b) are displaced farther south and east when compared with 

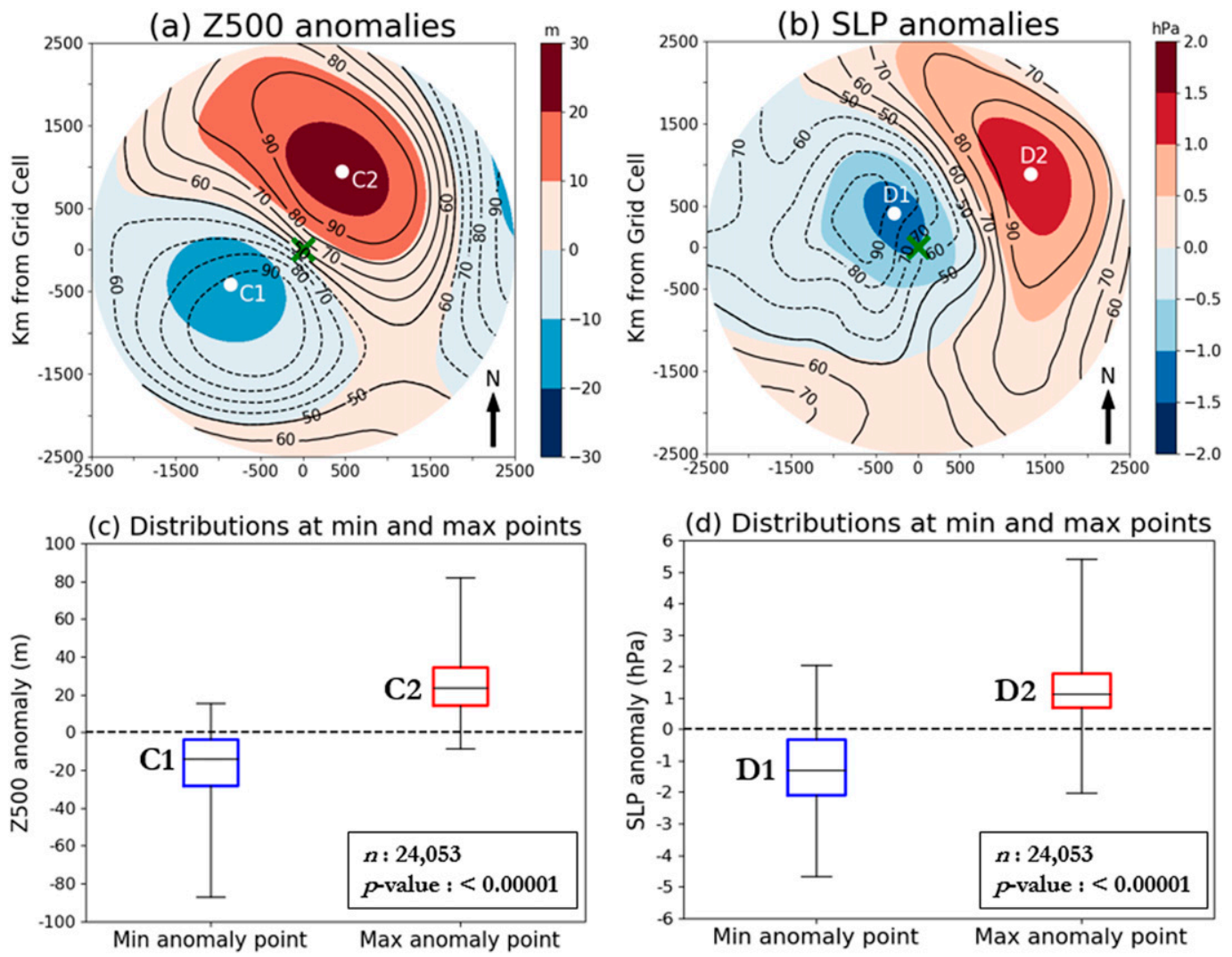

FIG. 3. (top) Grand composites of (a) Z500 and (b) SLP anomalies on lightning days for all 24053 grid cells in the domain, averaged from composites centered on each grid cell (green marker). Contours indicate percentage of all grid cells that feature positive (solid) or negative (dashed) anomalies at those locations relative to each grid cell. (bottom) Boxplots for (c) Z500 and (d) SLP show distributions of individual gridcell anomalies at the locations of anomaly peaks in the grand composites, with $t$-test results showing statistically significant differences between grand composite anomaly peaks.

pattern correlation values. Comparatively lower agreement (higher RMSD values) is found in areas of eastern Oregon, northern Idaho, and western Montana, in contrast to the generally high PC values in this region. Although some of this increase in RMSD may be attributed to smaller sample sizes introducing noise into the local composites, an important factor is the greater synoptic pattern amplitude across these areas on lightning days. An analysis of average pattern amplitude, or the difference between the highest and lowest local composite anomaly values relative to each grid cell on lightning days, reveals greater peak-to-peak spread in both Z500 and SLP anomaly fields in the northern and western parts of the domain (not shown). These values are collocated with areas of higher RMSD and can be attributed to locations where midlatitude dynamics play an increased role in thunderstorm formation, compared to regions farther south and east where mesoscale dynamics are more influential (Adams and Souza 2009). Areas of lower RMSD are concentrated in the central and southern portions of the domain, indicating local composites with weaker synoptic pattern amplitude and closer resemblance to the amplitude of grand composites in Figs. 3a and 3b. Additionally, an analysis of 200hPa geopotential height anomalies also reveals lower RMSD in the Four Corners region when compared to the interior northwestern United States (Fig. S3). Local composites in the core monsoon region are likely strongly influenced by the seasonal upper-tropospheric monsoon ridge centered over northwestern Mexico (Barlow et al. 1998).

Regional variability in Z500 pattern progression on days prior to analyzed lightning day is shown in Fig. 5, with PC coefficients indicating the closeness of match between the local composite at each grid cell and the local composites at 1,2, and 3 days prior for the same grid cell. Southern locations, near the monsoonal core, show little pattern progression in the three days prior to analyzed lightning day, as indicated by the relatively high PC values throughout, likely indicating more 
(a) Z500 correlation coefficients $(0.78)$

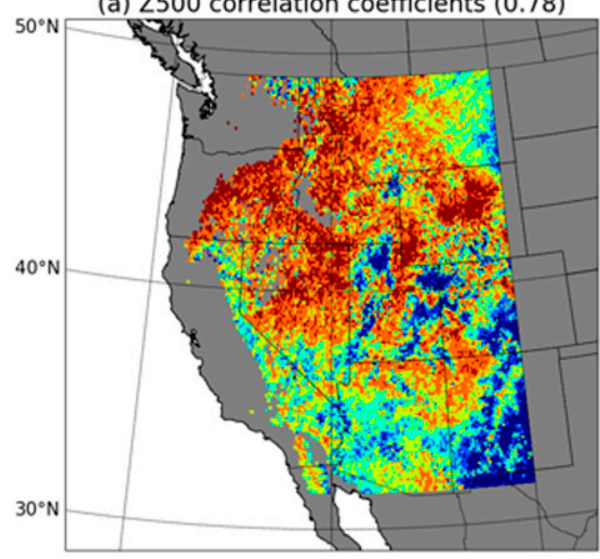

(c) SLP correlation coefficients $(0.71)$

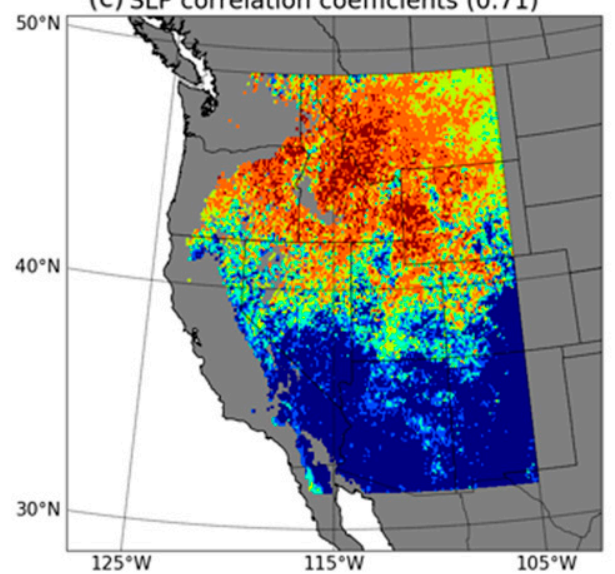

(b) Z500 RMSD from grand composite
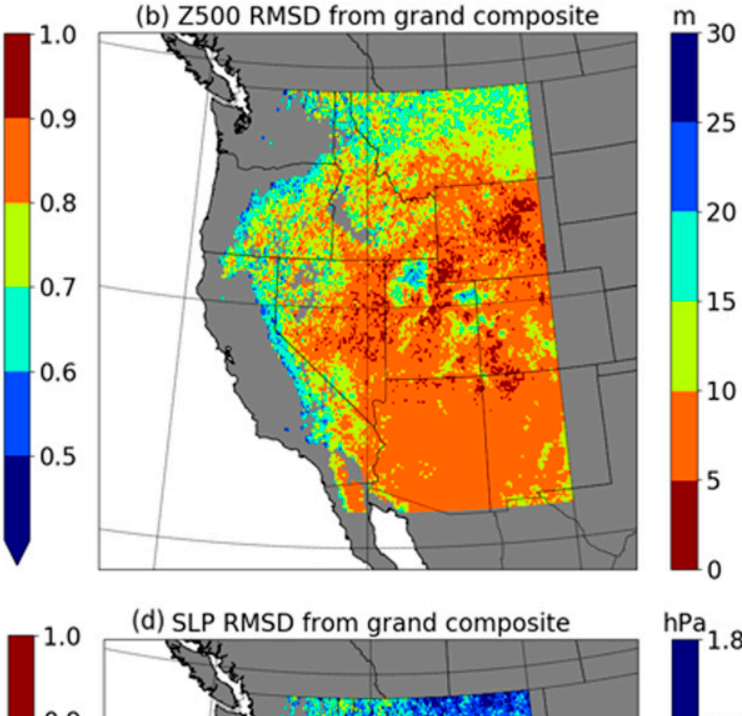

(d) SLP RMSD from grand composite

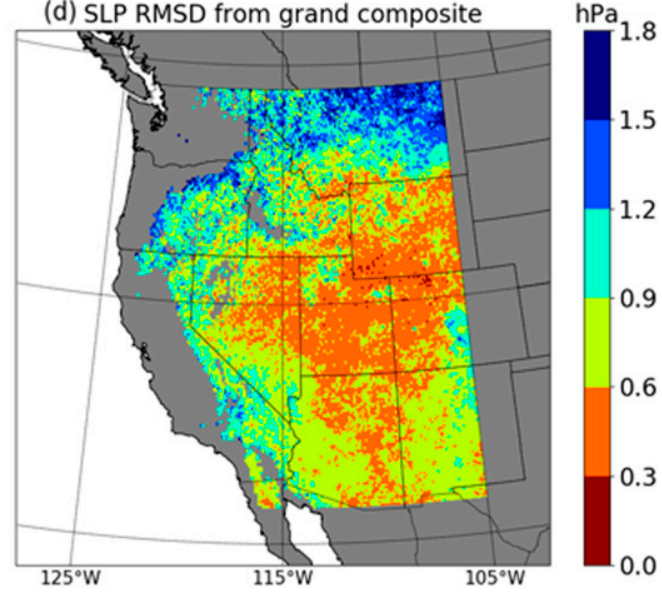

FIG. 4. (a),(c) Pattern correlation coefficients and (b),(d) RMSD statistics between each grid cell's local composite and the grand composite (see Figs. 3a,b) for (top) Z500 and (bottom) SLP. Values to the right of the subtitles in (a) and (c) represent the median pattern correlation coefficient between the grand composite and all local composites in the study domain. In all panels, values in red indicate high agreement on lightning days between the local composite pattern and the grand composite in sign in (a) and (c) or magnitude in (b) and (d).

persistent or frequent dynamics favorable to lightning days in this region. In addition, instances of multiple consecutive lightning days across this region, as described in Watson et al. (1994), may mask synoptic pattern transitions between multiday bursts and breaks in monsoon activity. Areas farther west, including the Sierra Nevada, also show little pattern progression, possibly reflecting multiday northward extension of upper-level ridging corresponding to lightning activity. This is in contrast to lower PC coefficients between days farther north, where pattern progression is likely driven by transient upper-level disturbances in the days leading up to lightning activity.

Figure 6 provides an indication of local composite "pattern representativeness." The values plotted are constructed by first computing the PC between the local Z500 pattern for each lightning day and the local composite pattern for that grid cell. This results in the same number of correlation coefficients as lightning days, and the mean of these coefficients is plotted. Lower values indicate that the local composite pattern is less representative of lightning day patterns compared to places with higher values. Lower values are found in areas to the southeast, indicating weaker pattern representativeness of lightning days at the gridcell level. Individual local composites at grid cells across these areas may mask multiple orientations of synoptic patterns during lightning outbreaks, as favorable dynamics are generally present in these areas during monsoon season. Previous studies have found a north-south gradient of increasing complexity in combinations of predictor variables favorable to lightning in western North America (Burrows et al. 2005), indicating climatologically more favorable conditions for lightning occurrence further south and less dependence on rare combinations of variables. Locations in the northern and western periphery in 

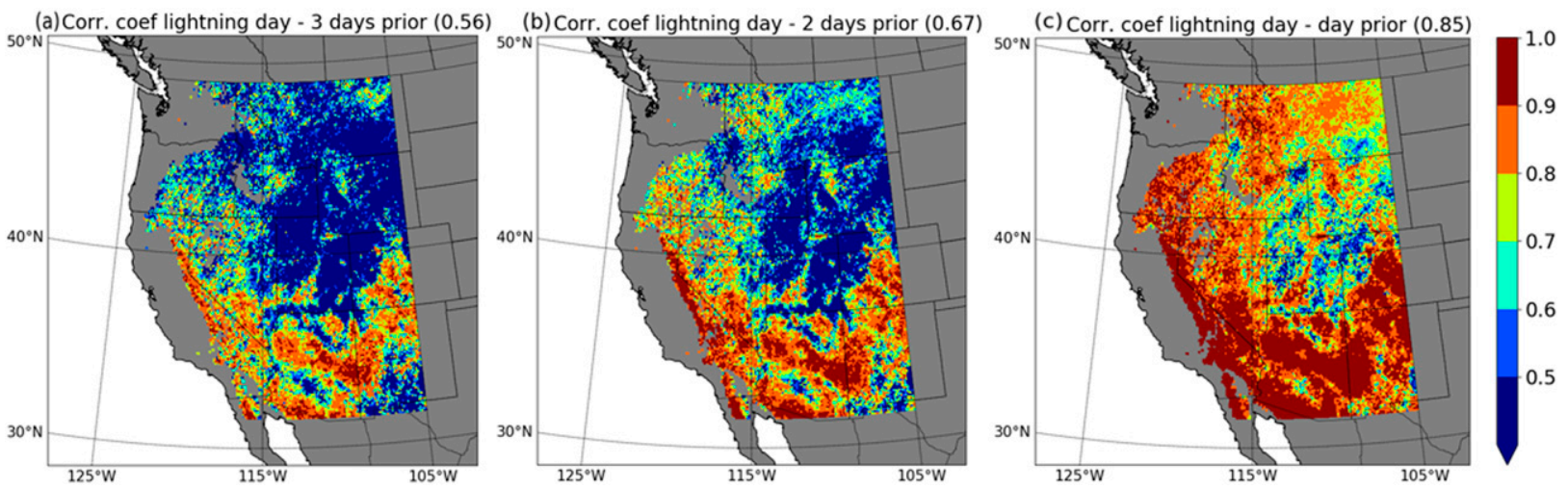

FIG. 5. Pattern correlation coefficients between local composite Z500 anomaly pattern on analyzed lightning day and local composite anomaly patterns (a) 3 days, (b) 2 days, and (c) 1 day prior at each grid cell, with values in red indicating high agreement between days. Values to the right of the subtitles represent the median pattern correlation coefficient across the domain for each 2-day pairing.

Fig. 6 show higher composite pattern representativeness, likely resulting from increased dependence on certain orientations of preferred synoptic patterns favorable to lightning activity in these areas.

Overall, our results reflect greater amplitude of synoptic patterns typically seen at higher latitudes during boreal summer when compared to the synoptic environment associated with the monsoonal circulation farther south. Areas of spatially coincident lower agreement in both PC values and RMSD for both Z500 and SLP are evident in parts of the study domain, indicating both lesser amplitude and differences in the spatial signature of the sign of anomaly patterns compared to the grand composites. These areas include the Sierra Nevada region as well as some interior basins, such as those containing the Great Salt Lake and the Green River in Utah. While a full analysis of responsible mechanisms for these regional differences is beyond the scope of this study, the influence of topography is speculated to drive most of these regional patterns of preferred lightning conditions.

\section{b. 700-hPa wind}

To further characterize lower-tropospheric circulation features associated with lightning activity, we explore the local 700-hPa wind directions prevalent on lightning days across the region. The dominant mode of W700 direction for each grid cell is presented in Fig. 7a, with wind directions binned into $45^{\circ}$ increments centered on the eight cardinal and intermediate compass bearings. The frequency of the dominant W700 direction at each grid cell in Fig. 7a is represented as a percentage of all directions in Fig. 7b. Dominant modes of W700 direction follow a general clockwise path along an arc from the low desert regions of Arizona and California (easterly to southeasterly), extending northward through the Great basin (southerly to southwesterly), and eastward into parts of the central and northern Rocky Mountains (southwesterly to westerly). Areas in central Arizona show weak preference for W700 direction on lightning days (Fig. 7b), likely reflecting the climatological position of the monsoon ridge with weak steering currents in the vicinity, along with the dominant role of mesoscale dynamics in thunderstorm formation across this region regardless of synoptic pattern. As an example, case studies of active lightning periods in Arizona have been associated with both southerly and northerly flow at the 700-hPa level (e.g., in Watson et al. 1994).

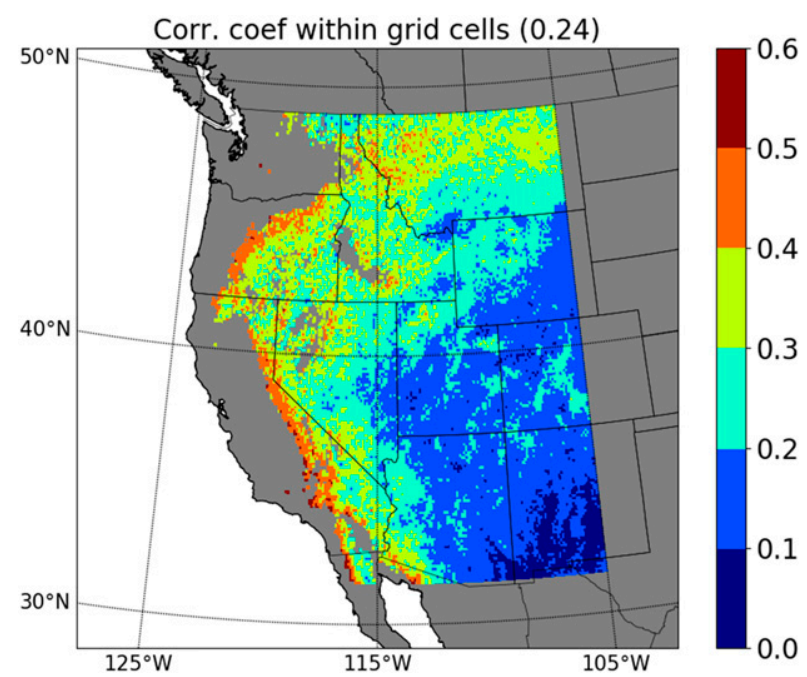

FIG. 6. "Pattern representativeness" computed as the mean pattern correlation coefficients of Z500 anomalies on lightning days within each grid cell's local composite and the local composite pattern itself, showing representativeness of local gridcell composite anomaly pattern for all grid cells. Value to the right of the title represents the median pattern correlation coefficient of all grid cells. 
(a) $700 \mathrm{hPa}$ wind dir., lightning days

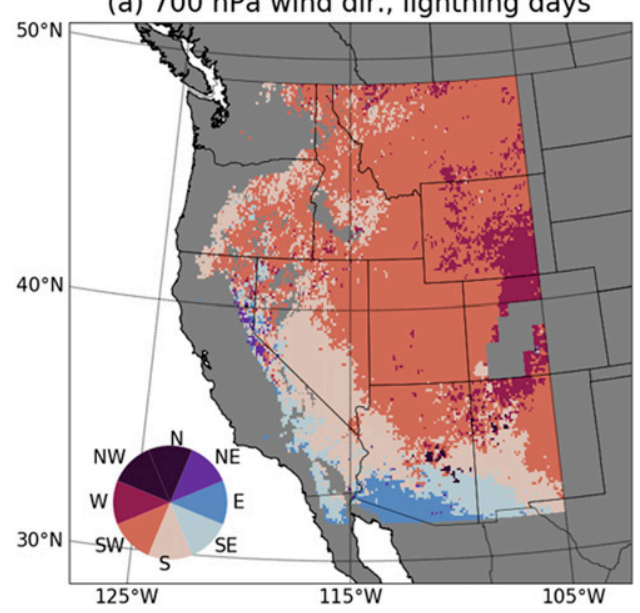

(b) \% of lightning days

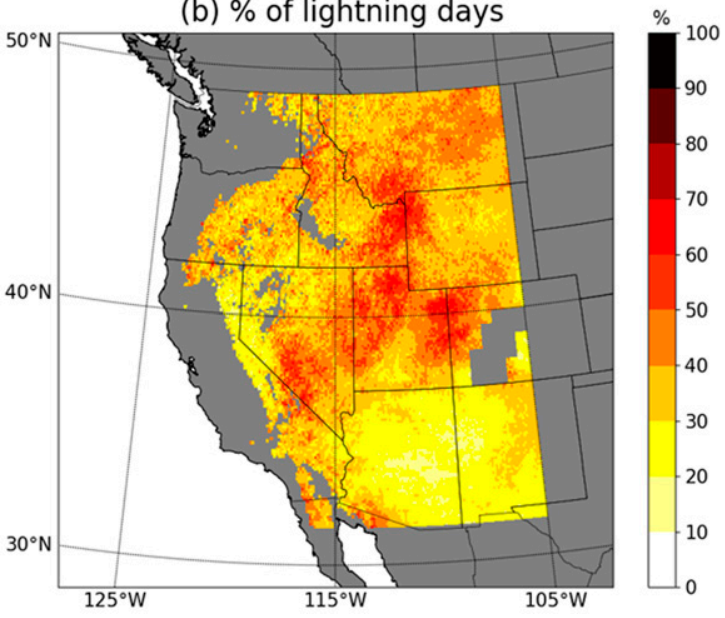

FIG. 7. The 700-hPa wind direction on lightning days at each grid cell, displayed as (a) the dominant directional mode binned into $45^{\circ}$ increments centered on the eight cardinal and intermediate compass bearings and (b) the associated frequency percentages for the dominant mode specific to each grid cell. Gray colors in western Colorado indicate reanalysis grid cells where surface elevation is above the 700-hPa pressure level.

Overall, our findings are consistent with the presence of mid- and upper-level ridging across the interior WUS during warm-season convective outbreaks, a synoptic feature cited in literature in association with lightning episodes in this region (e.g., Abatzoglou and Brown 2009). Northward extension of upper-level ridging promotes southerly flow in large areas of the interior WUS, specifically in areas north of the low-elevation deserts of the interior Southwest and east of the Sierra Nevada crest. In addition, a southwesterly flow component is introduced most likely by approaching upper-tropospheric troughs and cutoff lows associated with the breakdown of an upper-level ridge (Favors and Abatzoglou 2013), a feature illustrated by the prevalence of southwesterly flow in Fig. 7a. For areas on the southern margin of this flow regime, thunderstorm-conducive 700-hPa flow has been identified as southeasterly in both Arizona and New Mexico (Hales 1977; Higgins et al. 2004), and interior California (van Wagtendonk and Cayan 2008). Similarly, a southeasterly component in 500 -hPa flow direction has been identified as conducive to convective precipitation and lightning production specific to the east slopes of the Oregon Cascades (Chiodi et al. 2016).

\section{c. Moisture and instability}

Grand composites for anomalies of moisture (TQV) and instability (L700500) are presented in Figs. 8a and 8 b. Lightning days are characterized by greater positive anomalies across both variables in the vicinity of the grid cell experiencing lightning, with TQV exceeding one standard deviation relative to local climatologies of each grid cell (Fig. 8a). Other moisture variables were explored and showed similar positive anomalies in the composite patterns, with 2-m specific humidity also exceeding one standard deviation relative to local climatology near the grid cell experiencing a lightning day (not shown).

The grand composite of L700500 shows positive anomalies displaced to the north-northwest of each grid cell (Fig. 8b), indicating greater midtropospheric instability and roughly corresponding to the region of negative SLP anomalies in Fig. 3b. Average positive L700500 anomalies may reflect a combination of cooler air aloft advected by an incoming trough, as well as warmer than average surface temperatures associated with a residual surface thermal trough. When combined with the northeastward positive geopotential height anomalies in the grand composite Z500 pattern (Fig. 3a), this configuration strongly resembles the transitional weather pattern described in previous studies as conducive to increased wildfire risk in portions of the interior WUS (e.g., Werth and Ochoa 1993).

In Figs. $8 \mathrm{a}$ and 8b, dashed contours indicate a 500-km radius used to subset the larger $2500-\mathrm{km}$-radius grand composites of TQV and L700500 for further analysis. This subset radius was chosen after observation of central tendency of anomaly patterns relative to each grid cell, as can be observed from the distribution of elevated values within the larger grand composites. For each variable, all values in a $500-\mathrm{km}$-radius circular window around each grid cell are averaged and then assigned to that grid cell, allowing for a comparison of regional aggregate values relative to the set of lightning days at each grid cell. The resulting focal means quantify regional differences of moisture and instability anomalies not apparent in the grand composites. 

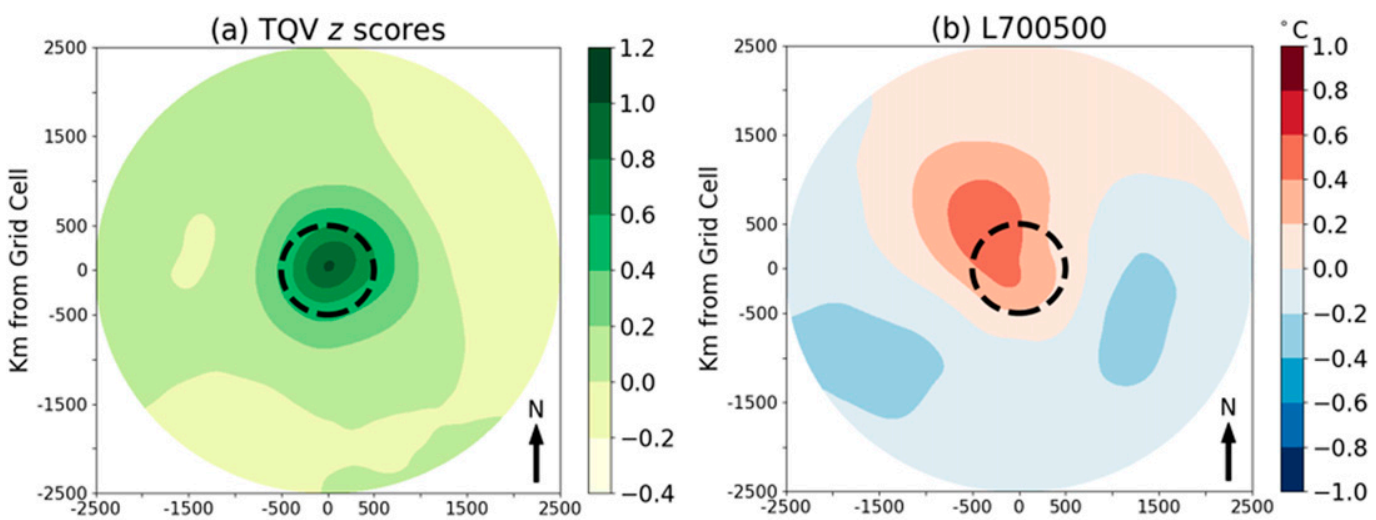

(c) Focal means
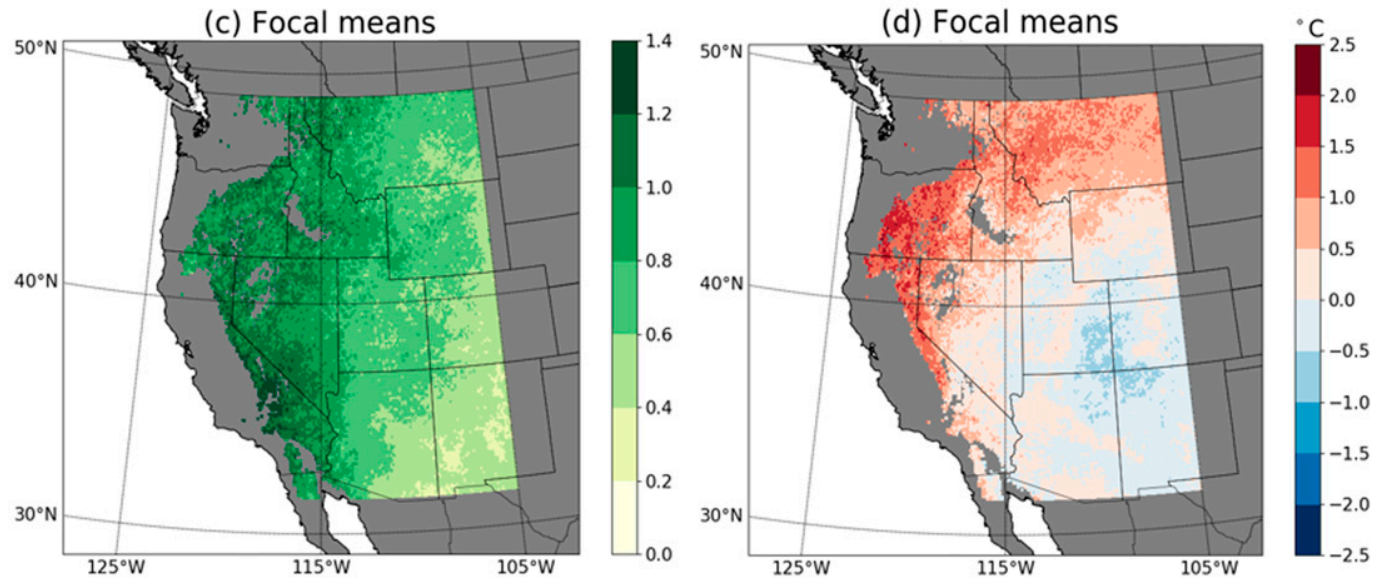

FIG. 8. Grand composites of (a) TQV, representing atmospheric moisture content, and (b) L700500, representing midtropospheric lapse rate, on lightning days. Note that standard deviation departures are used for TQV. Dashed contours indicate the $500-\mathrm{km}$ radius used to subset the grand composites for computation of focal means for (c) TQV and (d) L700500.

Focal means of TQV (Fig. 8c) and L700500 (Fig. 8d) anomalies reflect the divide between areas in the core monsoonal region and those on the periphery. Although standardized anomalies of TQV are positive throughout the study domain, departures are only slightly above daily mean values in parts of Arizona and New Mexico. Departures trend progressively more positive into the western Great Basin, interior California, and the interior Northwest. These findings are in agreement with summertime climatology across this region. Areas in the monsoonal core experience generally moist conditions during this season, which combine with high terrain to produce regularly recurring convective initiation and lightning production. Lightning days are more frequent in this region, and do not require atmospheric moisture quantities substantially above typical seasonal values. In addition, air mass thunderstorm days across this region likely move local composites further toward typical summer climatology. This is in contrast with areas farther west, which experience generally dry conditions during the summer season and thus require greater positive departures of moisture indices for thunderstorm formation. Our results are consistent with previous studies that have associated episodic northward moisture advection, away from typical monsoon areas, with lightning outbreaks across the arid western interior (e.g., Abatzoglou and Brown 2009; van Wagtendonk and Cayan 2008). Areas of interior California, in particular, show the greatest positive departures of TQV compared to local climatology in the study domain, likely reflecting the combination of typically dry conditions yielding to substantial moisture advection from proximate monsoonal areas on lightning days.

A regional divide is also observed in anomalies of L700500 (Fig. 8d), with positive departures in excess of $2^{\circ} \mathrm{C}$ in parts of Oregon and California. Anomalies of L700500 do not show a meaningful signal in the monsoonal core, with values on either side of zero on lightning days. This regime can also be interpreted in the context of differing summertime climatologies prevalent in these regions. Lightning days in the interior northwestern United States are strongly linked with anomalous 
upper-level ridging as well as incoming troughs during ridge breakdown, which promote steeper-than-average midtropospheric lapse rates. In the monsoonal core, there are weak anomalies in midtropospheric lapse rates. It is worth noting, however, that composites of values aggregated to a daily scale may not capture midlevel instability present during actual times of lightning occurrence in parts of this region, especially in valley locations prone to nocturnal thunderstorm maxima (Hales 1977).

\section{Select cases}

Regional variability in preferred lightning-conducive meteorological patterns is further illustrated through four select grid cells. Each grid cell is chosen to represent a different region of the study domain. Further, we choose two regions each to represent the northern and southern halves of the study domain. The regions correspond to central Oregon (COR), western Montana (WMT), eastern Sierra Nevada (ESN), and central Arizona (CAZ). Within each region, one grid cell is chosen for which composite fields are calculated.

Anomaly patterns of Z500 at the two northern areas (COR and WMT) reflect the grand composite in Fig. 3a, with a characteristic dipole anomaly arrangement and a transitional gradient apparent around both grid cells (Figs. 9a,b). In addition, the WMT composite strongly resembles the orientation of favorable 700-hPa height anomalies conducive to large lightning days in western Montana presented by Dettinger et al. (1999). COR and WMT composites agree with the PC maps in Fig. 4a for $\mathrm{Z500}$, as higher PC values are shown to concentrate in locations represented by these composites. These local composites therefore reflect the canonical upper-level circulation and surface pressure pattern associated with lightning outbreaks and wildfire ignition risk in the interior northwestern United States. Conversely, Z500 anomaly patterns differ at the two southern regions (ESN and CAZ) compared to their northern counterparts (Figs. 9c,d), reflecting generally weaker PC present in these regions when compared with the grand composite. The southern grid cells do not show substantial negative Z500 anomalies southwestward, indicating that transient upper-level disturbances play a less important role in triggering convection in the southern half of the study domain. However, both locations show positive Z500 anomalies displaced northward in the local composites. While positive Z500 anomaly centers are placed farther west when compared to COR and WMT, pattern commonality with the grand composite is partially retained as anomalous geopotential height rises northward relative to these locations appear to favor better convective dynamics.
Anomaly patterns of SLP at COR, WMT, and ESN (Figs. 10a-c) agree well with the grand composite in Fig. 3b, with negative anomalies present around the grid cell experiencing a lightning day as well as locations northwestward. The anomaly pattern at CAZ (Fig. 10d) differs from the other three locations and from the grand composite, as positive SLP anomalies are found at the grid cell experiencing a lightning day reflecting the lower-SLP PC found in this region in Fig. 4c. However, the north-northwestward orientation of increasingly negative SLP anomalies likely indicates the presence of southsoutheasterly flow at CAZ in addition to COR and ESN on lightning days, suggesting moisture transport from sources located to the south and southeast of these locations.

Two select cases of active lightning days are provided in Fig. 11, representing the highest daily totals of CG flash counts over the 30 -yr record when aggregated over the western and eastern portions of the domain, respectively. For areas with the highest CG flash density in northeastern Oregon (Fig. 11a), the arrangement of synoptic circulation anomalies on 5 September 2013 generally resembles the grand composites (Figs. 3a,b). Relative to these locations, a transitional gradient in Z500 anomalies is apparent, with positive anomalies to the northeast and negative anomalies to the southwest, along with negative SLP anomalies placed northwestward into southern British Columbia. The Z500 anomalies represented by this daily snapshot likely capture the optimal position of the upper-level disturbance for generating convection as it transited the region. Anomalies of Z500 relative to areas with the highest CG flash density in Arizona and Utah on 15 August 2003 (Fig. 11b) are explained by both the grand composite (Fig. 3a) and the CAZ composite (Fig. 9d), illustrating individual pattern variability on lightning days. While areas northeastward of these locations agree well with the grand composite in placement of the strongest positive Z500 anomalies on 15 August 2003, the CAZ composite better captures this daily pattern in areas westward, where negative Z500 anomalies are absent. The anomaly pattern of SLP relative to these locations resembles the CAZ composite (Fig. 10d) in contrast to the grand composite (Fig. 3b), as positive anomalies are found in areas with the highest CG flash density.

\section{Summary and concluding remarks}

We characterize the meteorological conditions associated with warm-season lightning days across the interior WUS utilizing a recent 30-yr baseline (1988-2017). As continuous ground-based lightning detection only extends to the 1980s in the WUS (Cummins and Murphy 2009; Dettinger et al. 1999), studies focusing on this 
(a) Central Oregon

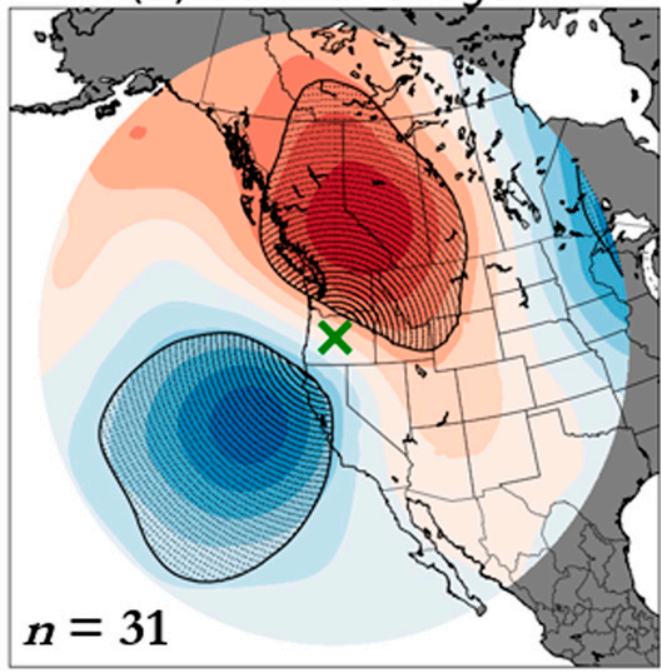

(c) Eastern Sierra Nevada

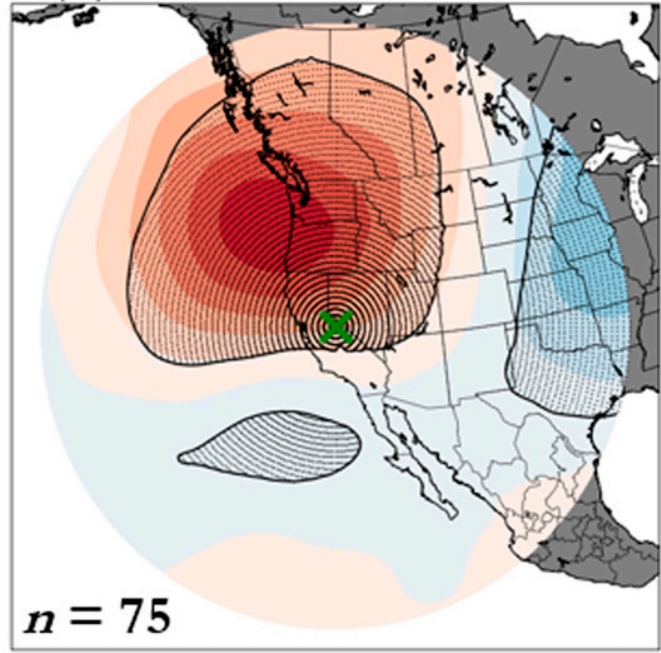

(b) Western Montana

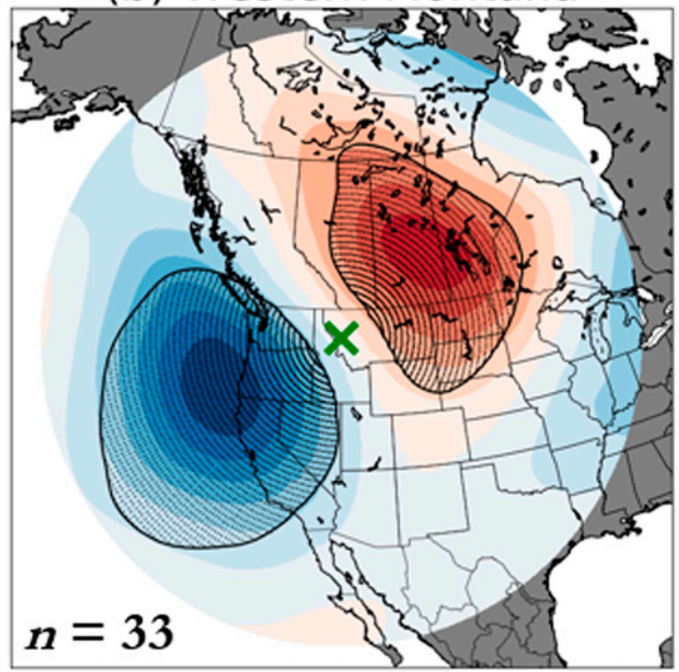

(d) Central Arizona

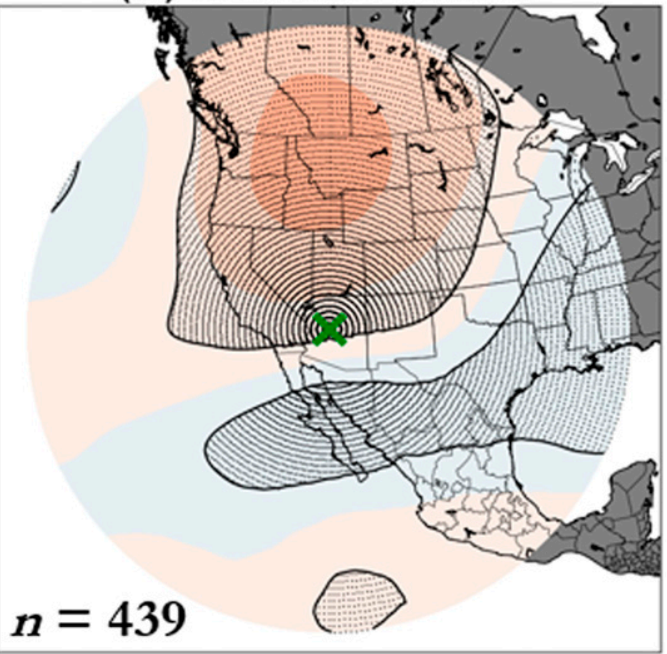

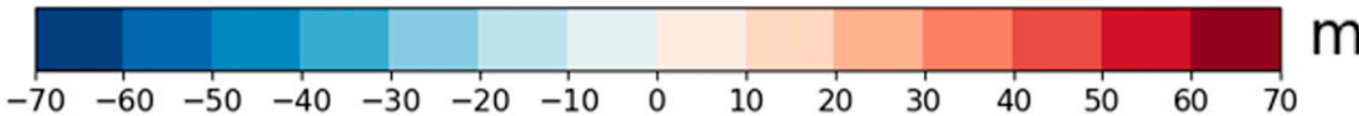

FIG. 9. Composites of Z500 for the four selected grid cells (green markers), with (a) central Oregon and (b) western Montana representing the northern half of the study domain and (c) eastern Sierra Nevada and (d) central Arizona representing the southern half. The sample size of lightning days $n$ is provided for each location. Statistically significant anomalies $(p$ value $<0.05)$ according to a $t$ test are denoted by black contours.

region have been constrained to shorter lightning datasets, typically between 5 and 20 years in length, which is suboptimal for climatological studies. This study benefits from a longer period of available CG lightning data, allowing for a more complete characterization of lightning climatology particularly in areas of infrequent thunderstorm activity outside of the core monsoon region of the WUS.

Local composites of dynamic and thermodynamic meteorological patterns for lightning days are constructed at each of the 24053 grid cells within the analysis scope, and all 24053 local composites are averaged to make a regionally representative single grand composite for each variable individually (Figs. 3 and 8). This composite analysis reveals that warm-season lightning days in the interior WUS are generally associated with positive Z500 anomalies displaced to the northeast of the location experiencing lightning with negative anomalies to the southwest, placing the lightning location in a transitional gradient on the synoptic scale. Z500 patterns are 
(a) Central Oregon

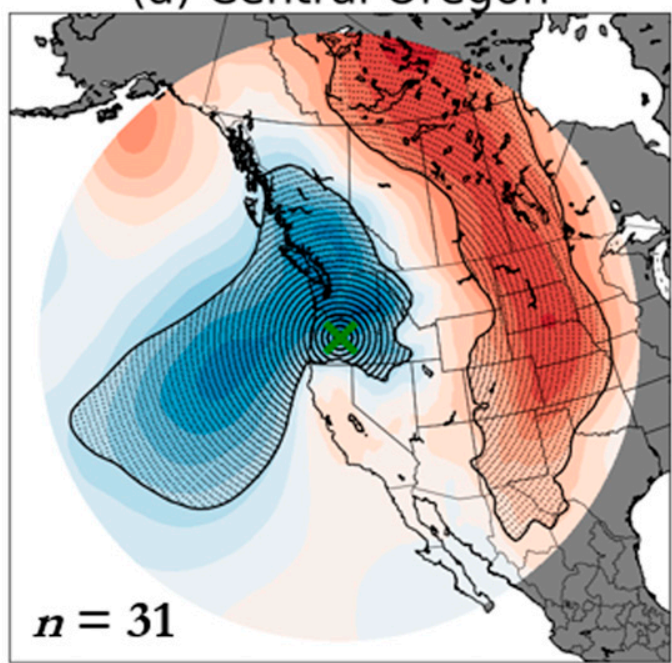

(c) Eastern Sierra Nevada

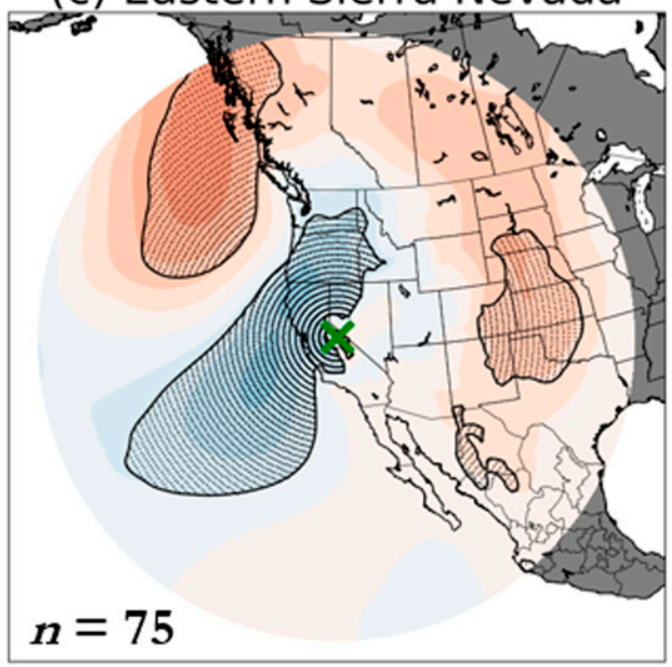

(b) Western Montana

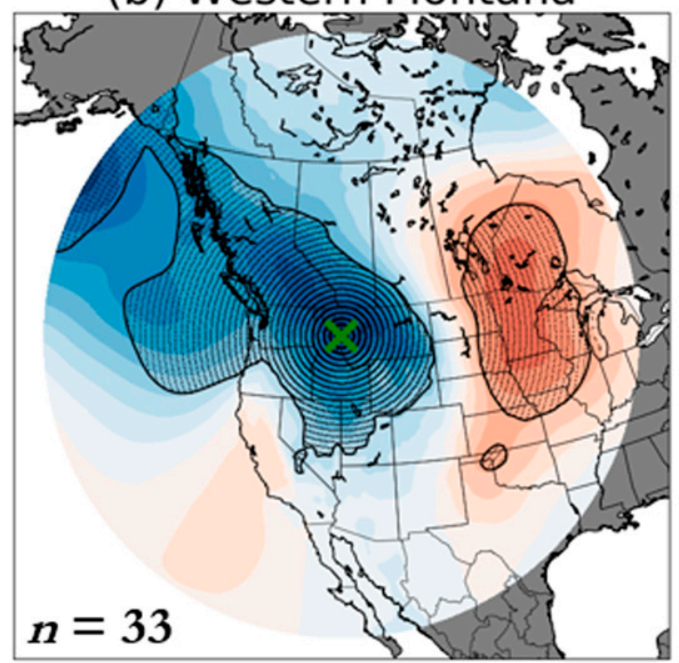

(d) Central Arizona

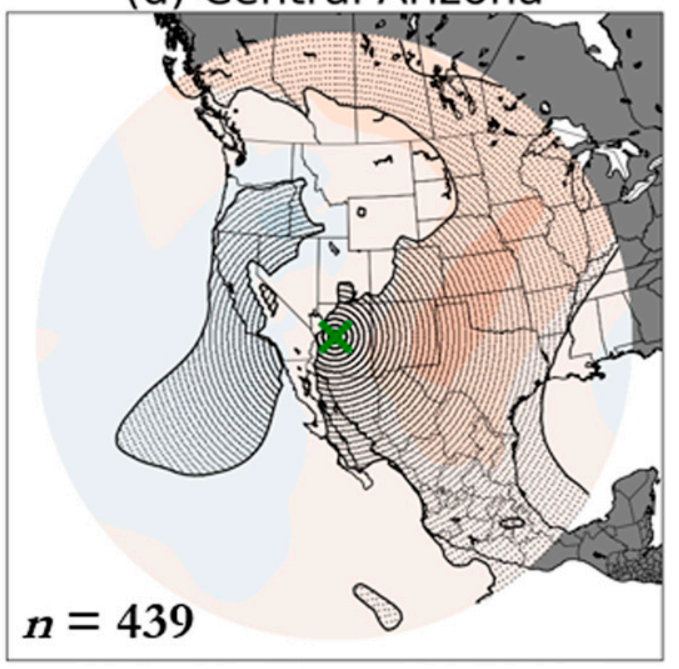

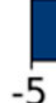

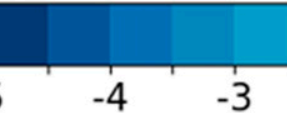

$-3$

$-2$

$-1$

0

1

2

3

$\mathrm{hPa}$

FIG. 10. As in Fig. 9, but for SLP.

shown to be more transient preceding lightning activity in areas farther north and in parts of the central Rockies, with little pattern progression on the preceding days in parts of the monsoonal core as well as interior California likely reflecting multiday persistence of lightning activity. Negative SLP anomalies are collocated and displaced northwest of the lightning location. Midlevel instability is also present in the grand composite average, as positive anomalies of L700500 show a similar spatial signature to negative SLP anomalies relative to each grid cell. In interior WUS, northward displacement of mid- and upper-level ridging generally leads to increased moisture advection and vertical instability during the warm season, allowing for lightning activity regardless of latitude particularly in topographically favored locations.

Analyzed fields generally reflect the regional divide between those areas under the direct influence of the summertime monsoon circulation, and those on the periphery. Local composites of anomalies of Z500 and SLP on lightning days exhibit generally stronger pattern correlation with grand composites in western and northern parts of the domain, although relatively high Z500 pattern correlation is also found in parts of the Southwest indicating preference for northward-displaced ridging (Fig. 4). A north-south divide in SLP pattern 
(a) 5-SEP-2013

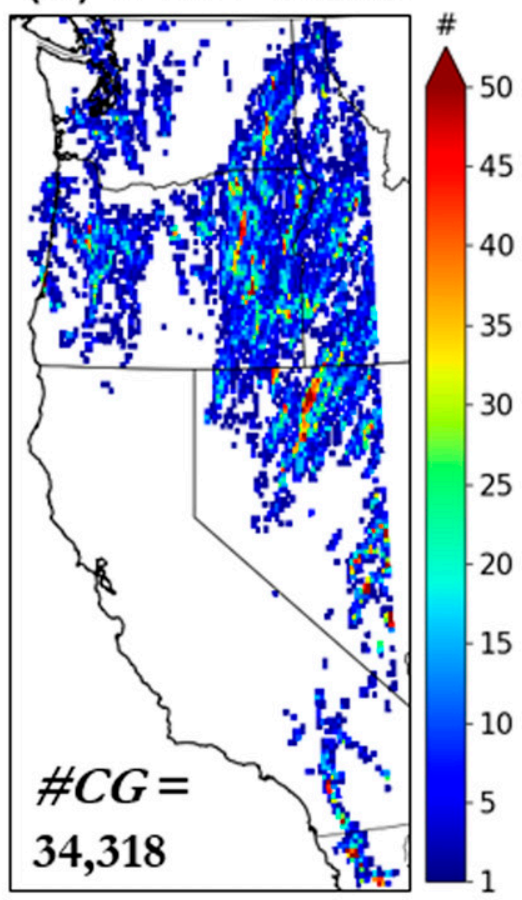

(b) 15-AUG-2003

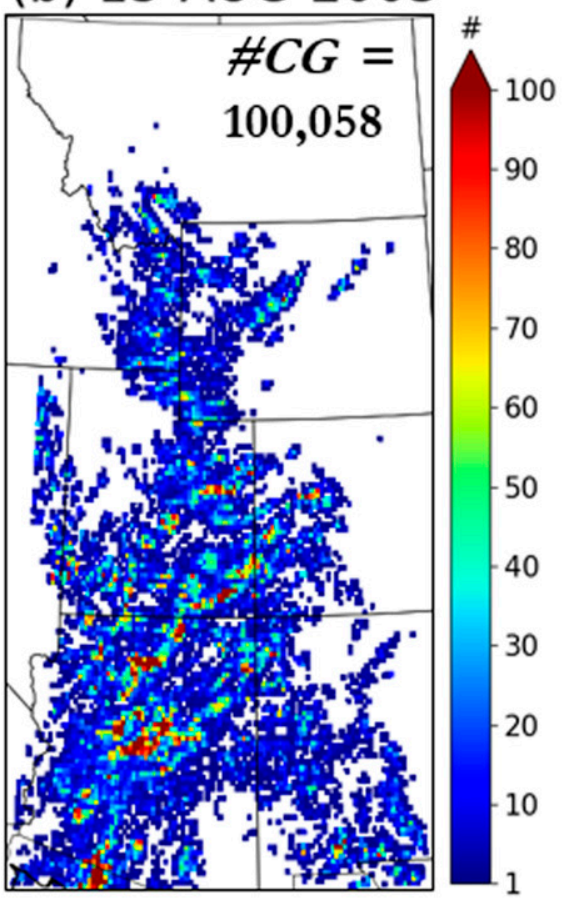

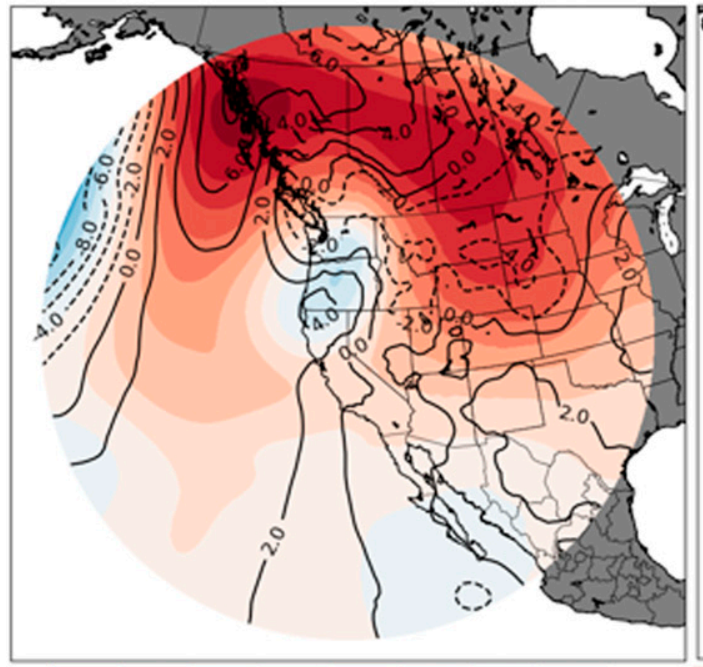

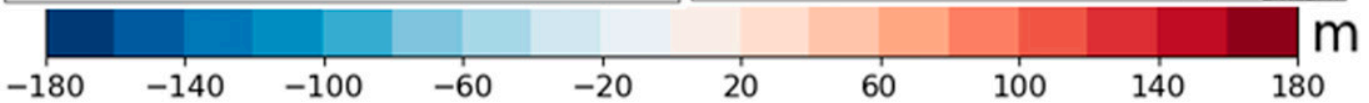

FIG. 11. Two case studies of active lightning days and associated Z500 (shaded) and SLP (contoured) anomaly patterns on those days. CG flash counts on 5 Sep 2013 (15 Aug 2003) were the highest daily totals in the 30-yr record when aggregated over the western (eastern) portion of the domain. Note that lightning scales differ between subplots.

correlation with the grand composite is evident across the domain, with lower correlation in the interior Southwest. The SLP grand composite captures features more common to midlatitude locations including negative SLP anomalies collocated and extending northwestward of lightning location, features absent in core monsoonal areas (such as the central Arizona example in Fig. 10d). On the monsoon periphery, thermodynamic indices experience episodic rises in association with lightning days, as both TQV and L700500 show substantially greater deviations from mean climatological values (Fig. 8). In the monsoonal core, weak L700500 
anomalies do not reflect a preference for increased midlevel instability compared to mean climatological values. Likewise, standardized anomalies of TQV are only weakly positive in the monsoonal core when compared to the substantially larger departures from climatology in areas farther north and west. W700 fields reflect the preferred regional circulation patterns described above. An easterly component is present across the southern periphery of the study area on lightning days, likely associated with a northward-displaced upperlevel high pressure ridge promoting easterly flow in these areas (Fig. 7). Locations to the north and west of the low desert regions show a strong preference for south-tosouthwesterly flow on lightning days. Favorable dynamics are likely introduced through transient upper-level disturbances displacing ridging northeastward, allowing for increased moisture advection and midlevel instability sufficient for lightning activity in these areas.

While our findings generally reinforce the known mechanisms associated with lightning occurrence across the WUS, our results offer a novel composite assessment of all interior WUS grid cells on lightning days. This comprehensive and spatially contiguous analysis helps identify commonalities in anomaly patterns relevant to the entire region such as northward-displaced positive Z500 anomalies, while highlighting regional differences. Aggregate metrics can be derived and applied to future climate model evaluation efforts, helping to understand possible future changes in lightning activity across this region. As metrics would be derived from a 30-yr climatology compiled by this study, more confidence can be placed in the evaluation of climate model simulations of future climate baselines. As lightning is a triggering mechanism for wildfire ignition, such efforts would carry important implications for possible changes to future wildfire regimes, in addition to changes in other thunderstormrelated impacts such as flash flooding.

Locations along transitional gradients of preferred anomaly patterns may be susceptible to changes in future lightning climatology resulting from relatively minor changes in associated meteorological variable fields, further necessitating the application of this work to projections of future climate change. Extension of this work may include compositing of anomaly patterns aggregated from smaller regions, with the goal of regional-scale climate model evaluation. Such an effort would be especially useful in the context of differing lightning climatologies in areas which are affected by, or are on the periphery of, the summertime monsoon circulation across the WUS, as well as locations strongly influenced by local topography.

Acknowledgments. NLDN data used in this study were obtained from National Oceanic and Atmospheric
Administration's Severe Weather Data Inventory (SWDI) database, available at https://www1.ncdc.noaa.gov/pub/ data/swdi/database-csv/v2/. MERRA-2 data used in this study were obtained from NASA's Goddard Earth Sciences Data Information Services Center (GES DISC), available at https://disc.gsfc.nasa.gov/. This work was carried out, in part, at the Jet Propulsion Laboratory, California Institute of Technology, and at Portland State University, under a contract from the National Aeronautics and Space Administration (NASA). Partial support for this work was provided by the NASA Enabling Tools for the National Climate Assessment (NCA) Program (D.A.K.) and by the NASA Indicators for the NCA Program (P.C.L.).

\section{REFERENCES}

Abarca, S. F., K. L. Corbosiero, and T. J. Galarneau, 2010: An evaluation of the Worldwide Lightning Location Network (WWLLN) using the National Lightning Detection Network (NLDN) as ground truth. J. Geophys. Res., 115, D18206, https://doi.org/10.1029/2009JD013411.

Abatzoglou, J. T., and T. J. Brown, 2009: Influence of the MaddenJulian oscillation on summertime cloud-to-ground lightning activity over the continental United States. Mon. Wea. Rev., 137, 3596-3601, https://doi.org/10.1175/2009MWR3019.1.

- C. A. Kolden, J. K. Balch, and B. A. Bradley, 2016: Controls on interannual variability in lightning-caused fire activity in the western US. Environ. Res. Lett., 11, 045005, https://doi.org/ 10.1088/1748-9326/11/4/045005.

Adams, D. K., and E. P. Souza, 2009: CAPE and convective events in the southwest during the North American monsoon. Mon. Wea. Rev., 137, 83-98, https://doi.org/10.1175/2008MWR2502.1.

Balch, J. K., B. A. Bradley, J. T. Abatzoglou, R. C. Nagy, E. J. Fusco, and A. L. Mahood, 2017: Human-started wildfires expand the fire niche across the United States. Proc. Natl. Acad. Sci. USA, 114, 2946-2951, https://doi.org/10.1073/pnas.1617394114.

Barlow, M., S. Nigam, and E. H. Berbery, 1998: Evolution of the North American monsoon system. J. Climate, 11, 2238-2257, https:// doi.org/10.1175/1520-0442(1998)011<2238:EOTNAM>2.0.CO;2.

Burrows, W. R., C. Price, and L. J. Wilson, 2005: Warm season lightning probability prediction for Canada and the northern United States. Wea. Forecasting, 20, 971-988, https://doi.org/ 10.1175/WAF895.1.

Chiodi, A. M., N. A. Bond, N. K. Larkin, and R. J. Barbour, 2016: Summertime rainfall events in eastern Washington and Oregon. Wea. Forecasting, 31, 1465-1480, https://doi.org/10.1175/ WAF-D-16-0024.1.

Cummins, K. L., and M. J. Murphy, 2009: An overview of lightning locating systems: History, techniques, and data uses, with an in-depth look at the U.S. NLDN. IEEE Trans. Electromagn. Compat., 51, 499-518, https://doi.org/10.1109/TEMC.2009.2023450.

Dettinger, M. D., D. R. Cayan, and T. J. Brown, 1999: Summertime intraseasonal and interannual lightning variations in the western United States. Proc. 24th Annual NOAA Climate Diagnostics and Prediction Workshop, Tucson, AZ, NOAA, 57-60.

Favors, J. E., and J. T. Abatzoglou, 2013: Regional surges of monsoonal moisture into the southwestern United States. Mon. Wea. Rev., 141, 182-191, https://doi.org/10.1175/MWRD-12-00037.1. 
Gelaro, R., and Coauthors, 2017: The Modern-Era Retrospective analysis for Research and Applications, version 2 (MERRA-2). J. Climate, 30, 5419-5454, https://doi.org/10.1175/JCLI-D16-0758.1.

Hales, J. E., 1977: On the relationship of convective cooling to nocturnal thunderstorms at Phoenix. Mon. Wea. Rev., 105, 1609-1613, https://doi.org/10.1175/1520-0493(1977)105<1609: OTROCC $>2.0 . \mathrm{CO} ; 2$.

Higgins, R. W., W. Shi, and C. Hain, 2004: Relationships between Gulf of California moisture surges and precipitation in the southwestern United States. J. Climate, 17, 2983-2997, https://doi.org/ 10.1175/1520-0442(2004)017<2983:RBGOCM>2.0.CO;2.

Hoogewind, K. A., M. E. Baldwin, and R. J. Trapp, 2017: The impact of climate change on hazardous convective weather in the United States: Insight from high-resolution dynamical downscaling. J. Climate, 30, $10081-10100$, https://doi.org/ 10.1175/JCLI-D-16-0885.1.

Krawchuk, M. A., M. A. Moritz, M.-A. Parisien, J. Van Dorn, and K. Hayhoe, 2009: Global pyrogeography: The current and future distribution of wildfire. PLOS ONE, 4, e5102, https:// doi.org/10.1371/journal.pone.0005102.

Loikith, P. C., and A. J. Broccoli, 2012: Characteristics of observed atmospheric circulation patterns associated with temperature extremes over North America. J. Climate, 25, 7266-7281, https://doi.org/10.1175/JCLI-D-11-00709.1.

Lorenz, D. J., and D. L. Hartmann, 2006: The effect of the MJO on the North American monsoon. J. Climate, 19, 333-343, https:// doi.org/10.1175/JCLI3684.1.

Magi, B. I., 2015: Global lightning parameterization from CMIP5 climate model output. J. Atmos. Oceanic Technol., 32, 434452, https://doi.org/10.1175/JTECH-D-13-00261.1.

Milne, R., 2004: A modified total totals index for thunderstorm potential over the Intermountain West. NWS WR Tech. Attachment 04-04, 15 pp., https://www.weather.gov/media/ wrh/online_publications/TAs/ta0404.pdf.

Nash, C. H., and E. A. Johnson, 1996: Synoptic climatology of lightning-caused forest fires in subalpine and boreal forests. Can. J. For. Res., 26, 1859-1874, https://doi.org/10.1139/x26-211.

Nauslar, N. J., B. J. Hatchett, T. J. Brown, M. L. Kaplan, and J. F. Mejia, 2019: Impact of the North American monsoon on wildfire activity in the southwest United States. Int. J. Climatol., 39, 1539-1554, https://doi.org/10.1002/joc.5899.

Orville, R. E., 2008: Development of the National Lightning Detection Network. Bull. Amer. Meteor. Soc., 89, 180-190, https://doi.org/10.1175/BAMS-89-2-180.

Price, C., 2009: Thunderstorms, lightning and climate change. Lightning: Principles, Instruments and Applications: Review of Modern Lightning Research, H. D. Betz, U. Schumann, and P. Laroche, Eds., Springer, 521-535.

— calculating global lightning distributions. J. Geophys. Res., 97, 9919-9933, https://doi.org/10.1029/92JD00719.

Romps, D. M., J. T. Seeley, D. Vollaro, and J. Molinari, 2014: Projected increase in lightning strikes in the United States due to global warming. Science, 346, 851-854, https://doi.org/ 10.1126/science.1259100.

Rorig, M. L., and S. A. Ferguson, 1999: Characteristics of lightning and wildland fire ignition in the Pacific Northwest. J. Appl. Meteor., 38, 1565-1575, https://doi.org/10.1175/1520-0450(1999) 038<1565:COLAWF $>2.0 . \mathrm{CO} ; 2$.

- S. J. McKay, S. A. Ferguson, and P. Werth, 2007: Modelgenerated predictions of dry thunderstorm potential. J. Appl. Meteor. Climatol., 46, 605-614, https://doi.org/10.1175/JAM2482.1.

van Wagtendonk, J. W., and D. R. Cayan, 2008: Temporal and spatial distribution of lightning strikes in California in relation to large-scale weather patterns. Fire Ecol., 4, 34-56, https:// doi.org/10.4996/fireecology.0401034.

Villarini, G., and J. A. Smith, 2013: Spatial and temporal variability of cloud-to-ground lightning over the continental U.S. during the period 1995-2010. Atmos. Res., 124, 137-148, https:// doi.org/10.1016/j.atmosres.2012.12.017.

Watson, A. I., R. L. Holle, and R. E. Lopéz, 1994: Cloud-toground lightning and upper-air patterns during bursts and breaks in the southwest monsoon. Mon. Wea. Rev., 122, 1726-1739, https://doi.org/10.1175/1520-0493(1994)122<1726: CTGLAU $>2.0 . \mathrm{CO} ; 2$.

Werth, P., and R. Ochoa, 1993: The evaluation of Idaho wildfire growth using the Haines index. Wea. Forecasting, 8, 223-234, https://doi.org/10.1175/1520-0434(1993)008<0223: TEOIWG $>2.0 . \mathrm{CO} ; 2$. 